\section{ACKNOWLEDGMENT}

This study was supported by grants of the National Research Foundation of Korea (NRF), funded by the Ministry of Science, ICT \& Future Planning (NRF-2017R1A2B400 6252), Korea Healthcare technology R\&D project, funded by Ministry of Health \& Welfare, Republic of Korea (HI17 C0597), and the Hallym University Research Fund (HURF2017-35, HURF-2017-52, HURF-2017-83).

\section{CONFLICTS OF INTEREST}

The authors have nothing to disclose.

\section{ORCID}

Min Je Jung, https://orcid.org/0000-0002-1037-2209

Bo Young Chung, https://orcid.org/0000-0002-2795-0140

Yong Won Choi, https://orcid.org/0000-0003-0607-5145

Jee Hee Son, https://orcid.org/0000-0002-7816-1942

Hye One Kim, https://orcid.org/0000-0001-5846-0008

Chun Wook Park, https://orcid.org/0000-0003-4512-8668

\section{REFERENCES}

1. Byun YS, Son JH, Cho YS, Yang YS, Cho HJ, Chung BY, et al. Cutaneous mixed infection of mycobacterium fortuitum and mycobacterium intracellulare after a fat graft. Korean J Dermatol 2016;54:459-463.

2. Lamb RC, Dawn G. Cutaneous non-tuberculous mycobacterial infections. Int J Dermatol 2014;53:1197-1204.

3. Bodle EE, Cunningham JA, Della-Latta P, Schluger NW, Saiman L. Epidemiology of nontuberculous mycobacteria in patients without HIV infection, New York City. Emerg Infect Dis 2008;14:390-396.

4. Lin SS, Lee CC, Jang TN. Soft tissue infection caused by rapid growing mycobacterium following medical procedures: two case reports and literature review. Ann Dermatol 2014;26:236-240.

5. Ngan GJ, Ng LM, Jureen R, Lin RT, Teo JW. Development of multiplex PCR assays based on the 16S-23S rRNA internal transcribed spacer for the detection of clinically relevant nontuberculous mycobacteria. Lett Appl Microbiol 2011; 52:546-554.

\title{
A Case of Perinevoid Alopecia on the Scalp
}

\author{
Seok Min Kim, Chihyeon Sohng, Jun Young Kim, Yong Hyun Jang, Seok-Jong Lee, Weon Ju Lee
}

Department of Dermatology, School of Medicine, Kyungpook National University, Daegu, Korea

\section{Dear Editor:}

Perinevoid alopecia is one of the atypical hair loss disorders $^{1}$. We describe a rare case of perinevoid alopecia. A 33-year-old woman presented with a solitary patch of alopecia with a central skin-colored papule on her vertex for
2 months (Fig. 1A). The match-head-sized skin-colored papule was observed when she was 10 years old, although the patch of alopecia was observed 2 months prior to presentation. Broken hairs were seen at the site of the patch of alopecia. There was no history of local irritation

Received December 11, 2017, Revised March 13, 2018, Accepted for publication April 9, 2018

Corresponding author: Weon Ju Lee, Department of Dermatology, Kyungpook National University Hospital, 130 Dongdeok-ro, Jung-gu, Daegu 41944, Korea. Tel: 82-53-420-5838, Fax: 82-53-426-0770, E-mail: weonju@knu.ac.kr ORCID: https://orcid.org/0000-0001-5708-1305

This is an Open Access article distributed under the terms of the Creative Commons Attribution Non-Commercial License (http://creativecommons.org/ licenses/by-nc/4.0) which permits unrestricted non-commercial use, distribution, and reproduction in any medium, provided the original work is properly cited.

Copyright (c) The Korean Dermatological Association and The Korean Society for Investigative Dermatology 

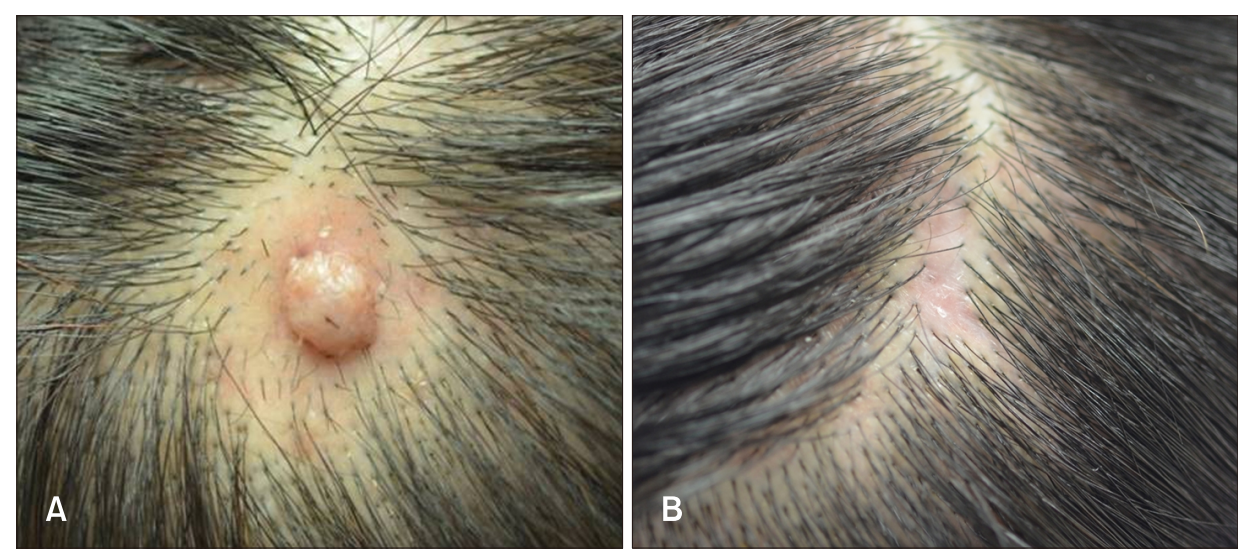

Fig. 1. (A) A solitary patch of alopecia with a central skin-colored papule on the vertex. (B) Regrowth of hair in the alopecic patch. We received the patient's consent form about publishing all photographic materials.
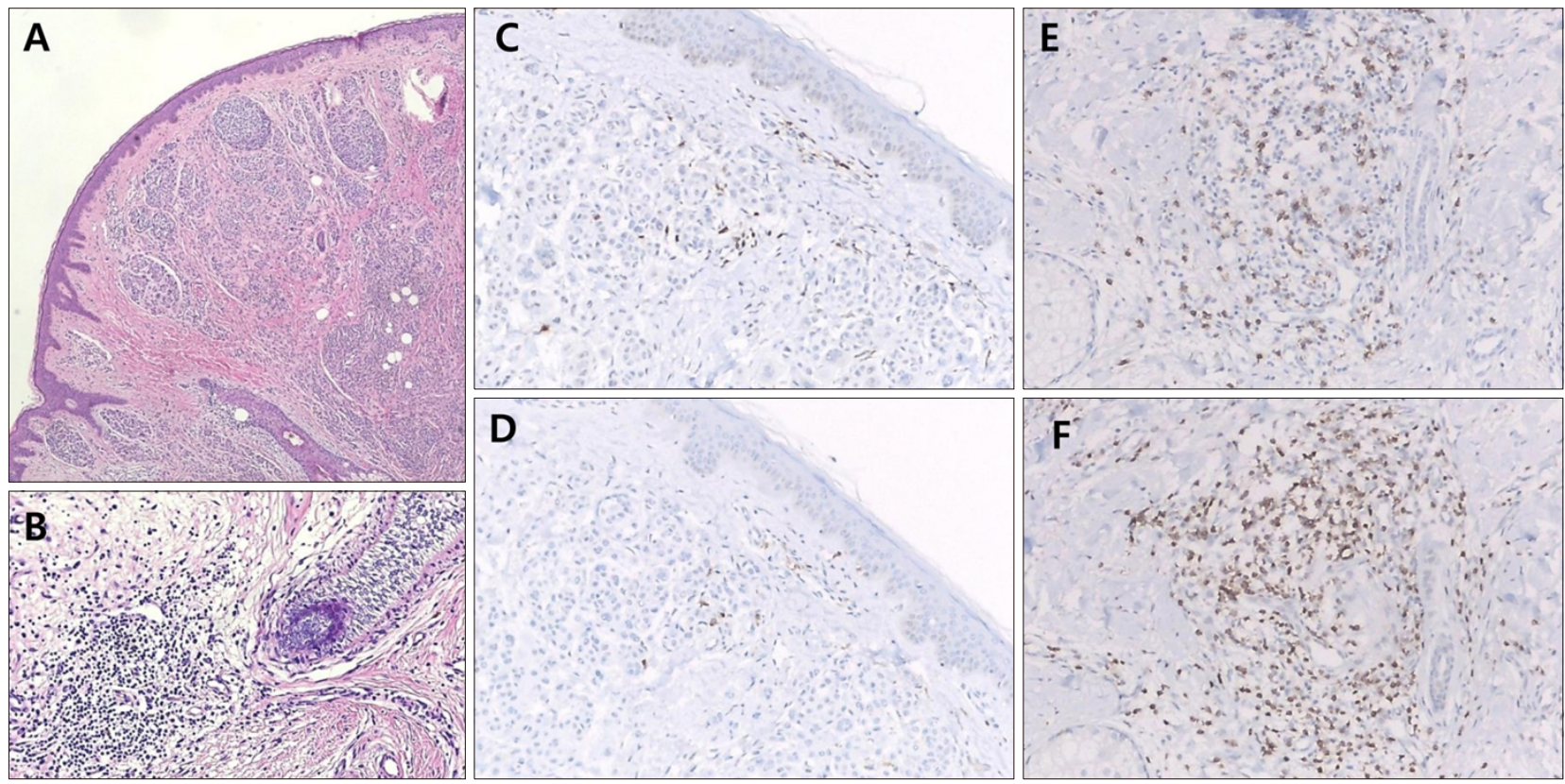

Fig. 2. (A) Numerous nevocytes and a sparse inflammatory cell infiltrate in the papule $(H \& E, \times 40)$. (B) $A$ hair follicle surrounded by an inflammatory cell infiltrate $(\mathrm{H} \& \mathrm{E}, \times 100)$. (C) CD3-positive inflammatory cells of the papule (immunohistochemistry, $\times 100$ ). (D) CD8-positive inflammatory cells of the papule (immunohistochemistry, $\times 100$ ). (E) CD3-positive inflammatory cells of the perifollicular area (immunohistochemistry, $\times 100$ ). (F) CD8-positive inflammatory cells of the perifollicular areas (immunohistochemistry, $\times 100$ ).

resulting in hair breakage. She reported an unremarkable past history and family history. Her laboratory findings were within the reference range. The central skin-colored papule was completely removed, and histopathologically this papule showed numerous nevocytes and a sparse inflammatory cell infiltrate (Fig. 2A). The periphery of the papule showed sparse hair follicles with perifollicular inflammatory cell infiltrates (Fig. 2B). The inflammatory cell infiltrates within the papule and at the periphery primarily comprised CD3- and CD8-positive cells (Fig. 2C F). Incidentally, follicular rupture with inflammatory infiltrate was shown under the nevus cell nests. She was diagnosed with perinevoid alopecia, and surgical removal of the central papule was followed by regrowth of hair at the affected site (Fig. 1B).

Perinevoid alopecia is an extremely rare disorder with a clinically distinctive feature of alopecic patch with central pigmented nevus and a histologically specific finding of inflammatory cell infiltration in nevus cell nests and perifollicular areas. Since Quiroga and Pecoraro ${ }^{2}$ reported a case of perinevoid alopecia in 1958, few cases have been published in the literature ${ }^{1}$. Previous reports have described the development of perinevoid alopecia on the scalp and the chin in young adults in whom this rare condition is commonly observed. Although pathogenesis of perinevoid alopecia is unclear, it may be similar to that as- 
sociated with the development of a halo nevus. Histopathological examination of a halo nevus shows dense inflammatory cell infiltrates invading the nevus cell nests in the upper dermis and degeneration of peripheral melanocytes $^{3}$. The inflammatory cells are observed to be CD3- or CD8-positive lymphocytes. In this patient who presented with perinevoid alopecia, histopathological examination also showed nevus and inflammatory cells at the site of the central nevus lesion and sparse hair follicles and perifollicular inflammatory cell infiltrates in the perinevoid area. Immunohistochemistry examination showed the inflammatory cells noted in this patient were CD8-positive lymphocytes. Gilhar et al. ${ }^{4}$ have described that the association between nevi and alopecia is attributable to an immunological reaction in that melanocyte-associated T-cell epitopes act as auto-antigens to induce an autoimmune reaction against hair follicles and nevus cells. We think incidental development of minute follicular rupture in this case was not associated with perinevoid alopecia. Although pseudocyst of scalp is a much more severe inflammatory disease of scalp, it does not develop perilesional alope$\mathrm{cia}^{5}$. Perinevoid alopecia can be effectively managed with surgical removal of the nevus.

\section{CONFLICTS OF INTEREST}

The authors have nothing to disclose.

\section{ORCID}

Seok Min Kim, https://orcid.org/0000-0001-6470-7986 Chihyeon Sohng, https://orcid.org/0000-0002-1452-7896 Jun Young Kim, https://orcid.org/0000-0002-2999-1018 Yong Hyun Jang, http://orcid.org/0000-0003-1706-007X Seok-Jong Lee, http://orcid.org/0000-0002-6131-632X

Weon Ju Lee, https://orcid.org/0000-0001-5708-1305

\section{REFERENCES}

1. Yesudian $P$, Thambiah AS. Perinevoid alopecia. An unusual variety of alopecia areata. Arch Dermatol 1976;112:14321434.

2. Quiroga M, Pecoraro V. Alopecia perinaevica. Hautarzt 1958;9:377-378.

3. Bayer-Garner IB, Ivan D, Schwartz MR, Tschen JA. The immunopathology of regression in benign lichenoid keratosis, keratoacanthoma and halo nevus. Clin Med Res 2004;2:8997.

4. Gilhar A, Landau M, Assy B, Shalaginov R, Serafimovich S, Kalish RS. Melanocyte-associated T cell epitopes can function as autoantigens for transfer of alopecia areata to human scalp explants on Prkdc(scid) mice. J Invest Dermatol 2001; 117:1357-1362.

5. Seol JE, Park IH, Kim DH, Park SH, Kang JN, Kim H, et al. Alopecic and aseptic nodules of the scalp/pseudocyst of the scalp: clinicopathological and therapeutic analyses in 11 Korean patients. Dermatology 2016;232:165-170. 